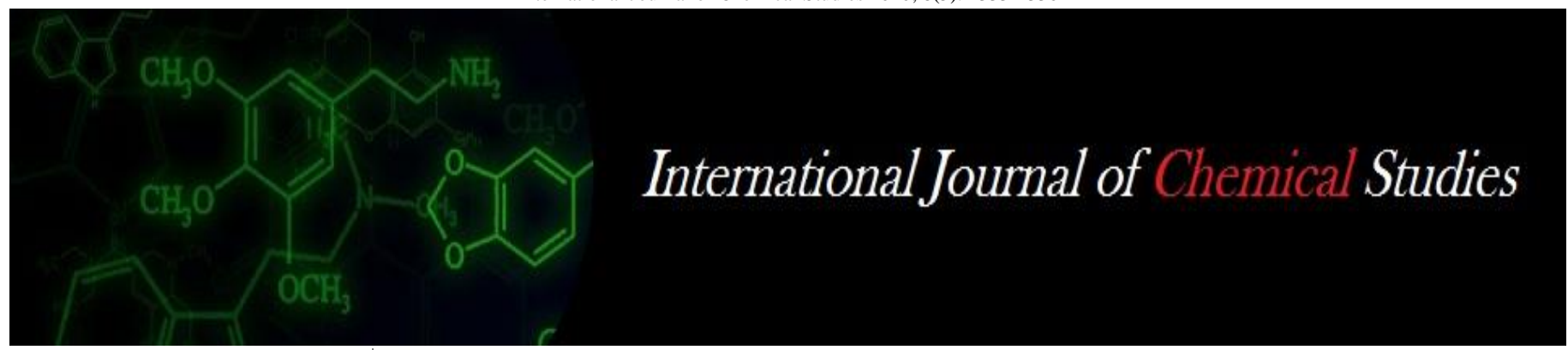

P-ISSN: 2349-8528

E-ISSN: 2321-4902

www.chemijournal.com

IJCS 2020; 8(5): 1333-1336

(C) 2020 IJCS

Received: 17-09-2020

Accepted: 19-10-2020

\section{Naqibullah Mujadidi}

Department of Horticulture,

Afghanistan National Agricultural

Sciences and Technology

University (ANASTU), Kandahar

Afghanistan

Sultan Mohammad Serat

Department of Horticulture,

Afghanistan National Agricultural

Sciences and Technology

University (ANASTU), Kandahar

Afghanistan

Najibullah Mujadadi

College of Horticulture, University of Horticultural Sciences campus,

GKVK post, Bengaluru, India

\section{Zmarialay Tani}

Department of Horticulture,

Afghanistan National Agricultural Sciences and Technology

University (ANASTU), Kandahar Afghanistan

MK Honnabyraiah

Department of Horticulture,

Afghanistan National Agricultural

Sciences and Technology

University (ANASTU), Kandahar

Afghanistan

\section{Fukrudin B}

Department of Horticulture,

Afghanistan National Agricultural

Sciences and Technology

University (ANASTU), Kandahar Afghanistan
Corresponding Author: Naqibullah Mujadidi Department of Horticulture,

Afghanistan National Agricultural Sciences and Technology University (ANASTU), Kandahar Afghanistan

\section{Effect of FYM and NPK on growth and yield of garlic (Allium sativum L.)}

\author{
Naqibullah Mujadidi, Sultan Mohammad Serat, Najibullah Mujadadi, \\ Zmarialay Tani, MK Honnabyraiah and Fukrudin B
}

DOI: https://doi.org/10.22271/chemi.2020.v8.i6s.10945

\begin{abstract}
The present investigation was conducted during winter season of 2017 at research farm of Agriculture Faculty, Department of Horticulture Kandahar University, Afghanistan the experiment was conducted in randomized block design with nine treatments and three replications. Effect of Garlic (Allium sativum L.) on growth and Yield to different levels of Nitrogen, Phosphorus and Potash (NPK). Doses 100:75:75 and 120:75:75 kg per hectare combination with farm yard manure (FYM), 20 and $25 \mathrm{t} \mathrm{ha}^{-1}$. The statistical analysis using F test revealed that FYM, NPK and combination of these two fertilizers significantly affected all growth and yield parameters studied. Maximum plant height $(56.25 \mathrm{~cm})$, was recorded in plots fertilized with NPK 120:75:75 $\mathrm{kg} \mathrm{ha}^{-1}+$ FYM $25 \mathrm{t} \mathrm{ha}^{-1}$, whereas maximum leaf length $(47.33 \mathrm{~cm})$, maximum number of leaves per plant (11.8), Maximum polar diameter of bulb $(6.22 \mathrm{~cm})$, maximum equatorial diameter of bulb $(5.16 \mathrm{~cm})$, fresh weight of bulb $(84.60 \mathrm{~g})$ and bulb yield $\left(19.55 \mathrm{tha}^{-1}\right)$.
\end{abstract}

Keywords: Allium sativum L. FYM, NPK, garlic, growth, yield

\section{Introduction}

Garlic (Allium sativum L.) is the second most widely used bulb crop after Onion (Allium cepa L.) which belongs to family Alliaceae. Garlic is sexually sterile and has traditionally been cultivated clonally through cloves. Garlic bulbs consist of small bulbils which range from 540 , called as cloves. India is the second large producer of garlic in the world. Garlic is rich source of sugar, protein, phosphorus, potassium, sulfur, iodine, fiber, and vitamins. Its pungent flavor makes it used mainly as a spice, seasoning and flavoring for foodstuff involving both green tops and bulbs. In India and other Asian and Middle East countries, it is used in pickles, curry powder, curried vegetables, meet preparation and tomato ketchup. Volatile oils comprise 0.1 to $0.25 \%$ of the fresh weight of garlic. Oil of garlic has now been appreciated as a valuable flavoring agent, for use in all kinds of meat preparation, soups, canned foods and sauces (Devendra et al. 2014) ${ }^{[3]}$. Garlic (Allium sativum L.) is a diploid species in the Allium genus of the Alliaceae family, order Asparagales. There are two subspecies within the species: ssp. sativum - common garlic and ssp. asiae mediae - Central Asian garlic. Each subspecies consists of two varieties: var. vulgare - common (non-bolting) and var. sagitatum - bolting garlic (Moravcevic et al. 2017) ${ }^{[10]}$.

FAO reported that Afghanistan also produce large number of Garlic vegetable after Onion cultivation and Its grown in vegetable gardens and with out vegetable garden in the house hold. Garlic and leek are grown in about one quarter or one fifth of the gardens. Here are 87,897 Garlic vegetable number of farms and also 10,356 farms with out vegetable garden in house hold.

Primary centre of origin of garlic is Central Asia, i.e., its highland area ranging from Afghanistan, throughout Northwest India, Tajikistan and Kyrgyzstan, and to a lesser degree the territory of China (to the Taklamakan desert), Kazakhstan, Uzbekistan and Turkmenistan. From this area, garlic has spread throughout the world. Garlic was considered to have lost its ability of generative reproduction during cultivation. However, in the last century, ecotypes with fertile seeds were found in the territory of Kazakhstan. The secondary centre of origin of garlic is the Mediterranean region.

China is the largest producer of garlic in the world, containing around $58 \%$ of the total world area with garlic $(856,500 \mathrm{ha})$. Owing to its high average annual yield (above $23 \mathrm{t} \mathrm{ha}^{-1}$ ), China 
accounts for $81 \%$ of the global output of garlic. The global

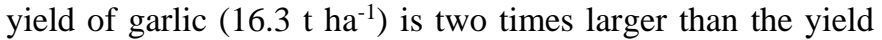
obtained in Europe.

Garlic (Allium sativum L.) commonly termed as "Lahsun", is one of the most important spices as well as bulb crop grown throughout in India because it's higher nutritive value as compared to the other bulbous crops. It is grown all over India on an area of 2.48 lakh hectares with total production of 12.59 lakh metric tons and having productivity of $5.1 \mathrm{MT} / \mathrm{ha}$.

Increase of garlic production has become of great importance to meet the ever increasing demand for local consumption and export. Such increase could be achieved by growing garlic in the reclaimed areas using organic manure for obtaining safe and healthy production than using inorganic fertilizers. Egypt occupied the fourth place in world for garlic production (301270 ton) in 2008 according to the Egyptian Statistics of Ministry of Agric. Organic manure is used as soil amendment, improved characters of sandy soil. It also, contained nutrients needed for onion crop production (Islah and M.El-Hifny 2010) [7]. Despite its importance, great potential for production and high market demand, the current garlic production and productivity is limited and seasonal. Low soil fertility is one of the factors limiting the productivity of garlic. Application of manure enhances soil fertility and increase the productivity of garlic by improving soil properties and nutrient status (Tadila et al. 2018) ${ }^{[12]}$.

Therefore, obvious choice is to maintain a natural balance for having a good soil health and to keep clean environment. Natural balance means application of organic/inorganic fertilizers in a balanced form, which is important in improvement in the quality of agricultural produce. The present study was designed to investigate the impact of FYM and NPK on Garlic plants grown under sandy loam soil conditions considering their growth and yield. Therefore, keeping in mind the above mentioned facts, the present experiment was carried out to find out the most suitable dose of FYM and NPK fertilizers for Garlic cultivars, in order to obtain better and higher yield and growth under the agroclimatic conditions of the Kandahar Afghanistan.

\section{Materials and Methods}

The field trial was conducted in a RBD with three replications and plot size of $2.25 \mathrm{~m}^{2}$ (spacing $10 \mathrm{~cm} \mathrm{x} 20 \mathrm{~cm}$ ) on Garlic cv. Punjab Garlic at research farm of Agriculture Faculty, Department of Horticulture Kandahar University, Afghanistan during Rabi season of 2017. FYM and NPK was applied as basal dose @ 100:75:75 and 120:75:75 kg ha-1 and FYM 20, $25 \mathrm{t} \mathrm{ha}^{-1}$ respectively. The obtain plant height, leaf length, number of leaves per plant, polar diameter of bulb $(\mathrm{cm})$, equatorial diameter of bulb $(\mathrm{cm})$, fresh weight of bulb $(\mathrm{g})$ and yield tonne ha-1 with application of $\mathrm{T}_{5}$ (farm yard manure $20 \mathrm{t}$ $\mathrm{ha}^{-1}+$ Nitrogen $100 \mathrm{~kg} \mathrm{ha}^{-1}+\mathrm{P}_{2} \mathrm{O}_{5} 75 \mathrm{~kg} \mathrm{ha}^{-1}+\mathrm{K}_{2} \mathrm{O} 75 \mathrm{~kg} \mathrm{ha}^{-1}$ ). Ten plants were randomly selected from each treatment. The data recorded on these factors were subjected to statistical analysis.

\section{Results and Discussion \\ Plant height (cm)}

The data pertaining to the plant height of garlic under different treatments recorded at 30, 50, 70, 90 and 110 days after sowing (DAS) is show in Table 1. Treatment $\mathrm{T}_{3}$ (farm yard manure $25 \mathrm{t} \mathrm{ha}^{-1}+$ Nitrogen $120 \mathrm{~kg} \mathrm{ha}^{-1}+\mathrm{P}_{2} \mathrm{O}_{5} 75 \mathrm{~kg} \mathrm{ha}^{-}$ $\left.{ }^{1}+\mathrm{K}_{2} \mathrm{O} 75 \mathrm{~kg} \mathrm{ha}^{-1}\right)$ recorded maximum plant height $(56.25 \mathrm{~cm})$ followed by $55.33 \mathrm{~cm}$ with $\mathrm{T}_{2}$ (farm yard manure $25 \mathrm{t} \mathrm{ha}^{-1}+$ Nitrogen $100 \mathrm{~kg} \mathrm{ha}^{-1}+\mathrm{P}_{2} \mathrm{O}_{5} 75 \mathrm{~kg} \mathrm{ha}^{-1}+\mathrm{K}_{2} \mathrm{O} 75 \mathrm{~kg} \mathrm{ha}^{-1}$ ) and the minimum $(38.67 \mathrm{~cm})$ was recorded with $\mathrm{T}_{0}$ (Control).
Similar trend was observed at subsequent growth stages also. On increasing the dose of FYM and NPK from 120:75:75 kg $\mathrm{ha}^{-1}+25 \mathrm{t} \mathrm{ha}^{-1}$ increase in plant height was recorded. On decreasing the dose of NPK from 120:75:75 $\mathrm{kg} \mathrm{ha}^{-1}+$ FYM $25 \mathrm{t} \mathrm{ha}^{-1}$ to NPK 100:75:75 kg ha-1 + FYM $25 \mathrm{t} \mathrm{ha}^{-1}$ decreasing the plant height slightly was recorded. Similar results were reported by Ahmed abbas et al. (2006) ${ }^{[1]}$.

\section{Length of leaves $(\mathrm{cm})$}

Length of leaves under different treatments counted and recorded at 30, 50, 70, 90 and 110 days after sowing (DAS) is shown in Table 1. Treatment $\mathrm{T}_{3}$ (FYM $25 \mathrm{t} \mathrm{ha}^{-1}+\mathrm{NPK}$ 120:75:75 $\left.\mathrm{kg} \mathrm{ha}^{-1}\right)$ recorded maximum length of leaves (47.33 $\mathrm{cm}$ ) followed by $45.92 \mathrm{~cm}$ with $\mathrm{T}_{2}$ (FYM $25 \mathrm{t} \mathrm{ha}^{-1}+\mathrm{NPK}$ $\left.100: 75: 75 \mathrm{~kg} \mathrm{ha}^{-1}\right)$ and the minimum $(31.17 \mathrm{~cm})$ was recorded with $\mathrm{T}_{0}$ (Control). Similar trend was observed at subsequent growth stages also. Better photosynthetic activity might have result higher length of leaves these findings are in consonance with the reports Banafer, R. N .S., Namdeo, S. L. and Asati, K. P. (2004) ${ }^{[2]}$..

\section{Number of leaves per plant}

Number of leaves per plant under different treatments counted and recorded at 30, 50, 70, 90 and 110 days after sowing (DAT) is shown in Table 1. Treatment $\mathrm{T}_{3}$ (FYM $25 \mathrm{t} \mathrm{ha}^{-1}$ +NPK 120:75:75 kg ha-1) recorded maximum number of leaves per plant (11.08) followed by 10.33 with $\mathrm{T}_{2}$ (FYM $25 \mathrm{t}$ $\mathrm{ha}^{-1}+$ NPK 100:75:75 $\mathrm{kg} \mathrm{ha}^{-1}$ ) and the minimum (6.83) was recorded with $\mathrm{T}_{0}$ (Control). Similar trend was observed at subsequent growth stages also. On decreasing the dose of NPK from 120:75:75 kg ha-1 + FYM $25 \mathrm{t} \mathrm{ha}^{-1}$ to NPK 100:75:75 kg ha-1 + FYM $25 \mathrm{t} \mathrm{ha}^{-1}$ decreasing the number of leaves per plant slightly was recorded. These findings are in consonance with the reports Gowda MC et al. (2007) ${ }^{[6]}$.

\section{Neck diameter $(\mathrm{cm})$}

Neck diameter under different treatments counted and recorded at 30, 50, 70, 90 and 110 days after sowing (DAT) is shown in Table 1.Treatment $\mathrm{T}_{3}$ (FYM $25 \mathrm{t} \mathrm{ha}^{-1}+\mathrm{NPK}$ 120:75:75 $\left.\mathrm{kg} \mathrm{ha}^{-1}\right)$ recorded maximum neck diameter $(1.90$ $\mathrm{cm}$ ) followed by $1.81 \mathrm{~cm}$ with $\mathrm{T}_{2}$ (FYM $20 \mathrm{t} \mathrm{ha}^{-1}+\mathrm{NPK}$ $\left.120: 75: 75 \mathrm{~kg} \mathrm{ha}^{-1}\right)$ and the minimum $(1.39 \mathrm{~cm})$ was recorded with $\mathrm{T}_{0}$ (Control). Similar trend was observed at subsequent growth stages also. Neck diameter increased with the increase in doses of FYM and NPK at all the stages of growth. Combination of FYM 20, $25 \mathrm{t} \mathrm{ha}^{-1}+$ NPK 100:75:75 and 120:75:75 kg ha ${ }^{-1}$ recorded maximum neck diameter. Better photosynthetic activity might have result higher neck diameter. Similar results were reported by Kakar, A.A., M.K. Abdullahzai, M. Saleem and S.A. Qaim, (2002) ${ }^{[8]}$.

\section{Size of bulb in polar diameter $(\mathrm{cm})$}

Size of bulb in polar diameter under different treatments recorded at is presented in Table 2. The table indicates that the effect of size of bulb in polar diameter at different treatments significant effect was observed. Treatment $\mathrm{T}_{5}$ $\left(\right.$ FYM $20 \mathrm{t} \mathrm{ha}^{-1}+$ NPK 100:75:75 $\mathrm{kg} \mathrm{ha}^{-1}$ ) recorded maximum equatorial diameter $(6.22 \mathrm{~cm})$ followed by $5.83 \mathrm{~cm}$ with $\mathrm{T}_{6}$ (FYM $20 \mathrm{t} \mathrm{ha}^{-1}+$ NPK 120:75:75 $\mathrm{kg} \mathrm{ha}^{-1}$ ) and the minimum $(4.18 \mathrm{~cm})$ was recorded with $\mathrm{T}_{0}$ (Control). Similar results were reported by Kilgori, M.J, M.D. Magaji, and A.I. Yakubu, (2007) ${ }^{[9]}$.

\section{Size of bulb in equatorial diameter $(\mathrm{cm})$}

Size of bulb in equatorial diameter under different treatments recorded at is presented in Table 2. The table indicates that 
the effect of size of bulb in equatorial diameter at different treatments significant effect was observed. Treatment $T_{5}$ (FYM $20 \mathrm{t} \mathrm{ha}^{-1}+$ NPK 100:75:75 $\mathrm{kg} \mathrm{ha}^{-1}$ ) recorded maximum equatorial diameter $(5.16 \mathrm{~cm})$ followed by $4.73 \mathrm{~cm}$ with $\mathrm{T}_{6}$ (FYM $20 \mathrm{t} \mathrm{ha}^{-1}+$ NPK 120:75:75 kg ha-1) and the minimum $(3.95 \mathrm{~cm})$ was recorded with $\mathrm{T}_{0}$ (Control). Similar results were reported by Tadila, G., \& Nigusie, D. (2018) ${ }^{[12]}$.

\section{Fresh weight of bulb (g)}

Fresh weight under different treatments recorded at is presented in Table 2. The table indicates that the effect of fresh weight at different treatments significant effect was observed. Treatment T5 (FYM $20 \mathrm{t} \mathrm{ha}^{-1}+$ NPK 100:75:75 kg $\mathrm{ha}^{-1}$ ) recorded maximum fresh weight of bulb (84.60 g) followed by $76.17 \mathrm{~g}$ with $\mathrm{T}_{6}$ (FYM $20 \mathrm{t} \mathrm{ha}^{-1}+\mathrm{NPK}$ 120:75:75 $\left.\mathrm{kg} \mathrm{ha}^{-1}\right)$ and the minimum $(34.90 \mathrm{~g})$ was recorded with $\mathrm{T}_{0}$ (Control). Similar trend was observed at subsequent growth stages also. Fresh weight of bulb increased with the increase in doses of FYM and NPK, at all the stages of growth. Combination of FYM $20 \mathrm{t} \mathrm{ha}^{-1}+$ NPK 100:75:75 and 120:75:75 $\mathrm{kg} \mathrm{ha}^{-1}$ recorded maximum fresh weight. Better photosynthetic activity might have result higher fresh weight. Similar results were reported by Singh, S. Yadav, P.K. and Singh, B. (2004) ${ }^{[11]}$.

\section{Yield per hectare $\left(\mathbf{q} \mathbf{h a}^{-1}\right)$}

Yield per hectare under different treatments recorded at is presented in Table 2. The table indicates that the effect of yield per hectare at different treatments significant effect was observed. Treatment $\mathrm{T}_{5}$ (FYM $20 \mathrm{t} \mathrm{ha}^{-1}+$ NPK 100:75:75 kg $\left.\mathrm{ha}^{-1}\right)$ recorded maximum yield per hectare $\left(195.55 \mathrm{q} \mathrm{ha}^{-1}\right)$ followed by $157.44 \mathrm{t} \mathrm{ha}^{-1}$ with $\mathrm{T}_{6}$ (FYM $20 \mathrm{t} \mathrm{ha}^{-1}+\mathrm{NPK}$ $\left.120: 75: 75 \mathrm{~kg} \mathrm{ha}^{-1}\right)$ and the minimum (71.11 $\left.\mathrm{q} \mathrm{ha}^{-1}\right)$ was recorded with $\mathrm{T}_{0}$ (Control). Yield per hectare Fresh weight of bulb increased with the increase in doses of FYM and NPK, at all the stages of growth. Combination of FYM $20 \mathrm{t} \mathrm{ha}^{-1}+$ NPK 100:75:75 and 120:75:75 $\mathrm{kg} \mathrm{ha}^{-1}$ recorded maximum yield per hectare. Treatment $\mathrm{T}_{5}\left(\mathrm{FYM} 20 \mathrm{t} \mathrm{ha}^{-1}+\mathrm{NPK}\right.$ 100:75:75 $\mathrm{kg} \mathrm{ha}^{-1}$ ) proved to be the appropriate combination of FYM and NPK, which emerged as superior over all other treatments for yield of Garlic. Similar results were reported by Tadila, G., \& Nigusie, D. (2018) ${ }^{[12]}$

Table 1: Effect of different combinations of FYM and NPK on Plant height $(\mathrm{cm})$, Length of leaves $(\mathrm{cm})$, Number of leaves per plant and Neck diameter $(\mathrm{cm})$ of Garlic (Allium sativum $\mathrm{L}$.) at different intervals.

\begin{tabular}{|c|c|c|c|c|c|}
\hline $\begin{array}{c}\text { Treatment } \\
\text { No. }\end{array}$ & Treatments & Plant height $(\mathrm{cm})$ & Length of leaves $(\mathrm{cm})$ & Number of leaves per plant & tNeck diameter $(\mathrm{cm})$ \\
\hline $\mathrm{T}_{0}$ & Control & 38.67 & 31.17 & 6.83 & 1.39 \\
\hline $\mathrm{T}_{1}$ & FYM $25 \mathrm{t} \mathrm{ha}^{-1}$ & 53.92 & 44.42 & 9.00 & 1.56 \\
\hline $\mathrm{T}_{2}$ & FYM $25 \mathrm{t} \mathrm{ha}^{-1}+\mathrm{NPK} 100: 75: 75 \mathrm{~kg} \mathrm{ha}^{-1}$ & 55.33 & 45.92 & 10.33 & 1.81 \\
\hline $\mathrm{T}_{3}$ & FYM $25 \mathrm{t} \mathrm{ha}^{-1}+$ NPK 120:75:75 $\mathrm{kg} \mathrm{ha}^{-1}$ & 56.25 & 47.33 & 11.08 & 1.90 \\
\hline $\mathrm{T}_{4}$ & FYM $20 \mathrm{t} \mathrm{ha}^{-1}$ & 50.83 & 39.33 & 9.08 & 1.76 \\
\hline $\mathrm{T}_{5}$ & FYM $20 \mathrm{t} \mathrm{ha}^{-1}+$ NPK 100:75:75 $\mathrm{kg} \mathrm{ha}^{-1}$ & 54.08 & 42.58 & 11.08 & 1.79 \\
\hline $\mathrm{T}_{6}$ & FYM $20 \mathrm{t} \mathrm{ha}^{-1}+$ NPK 120:75:75 $\mathrm{kg} \mathrm{ha}^{-1}$ & 53.58 & 44.08 & 10.83 & 1.65 \\
\hline $\mathrm{T}_{7}$ & NPK 100:75:75 $\mathrm{kg} \mathrm{ha}^{-1}$ & 48.17 & 36.83 & 9.08 & 1.58 \\
\hline $\mathrm{T}_{8}$ & NPK 120:75:75 kg ha-1 & 49.75 & 39.25 & 8.75 & 1.65 \\
\hline & $\begin{array}{c}\text { F-test } \\
\text { S.Ed. }( \pm), \text { C. D. }(P=0.05)\end{array}$ & $\begin{array}{c}\mathrm{S} \\
2.578,5.321\end{array}$ & $\begin{array}{c}\mathrm{S} \\
3.605,7.441\end{array}$ & $\begin{array}{c}\mathrm{S} \\
0.849,1.752\end{array}$ & $\begin{array}{c}\mathrm{S} \\
0.128,0.264\end{array}$ \\
\hline
\end{tabular}

Table 2: Effect of different combinations of FYM and NPK on polar diameter of bulb (cm), equatorial diameter of bulb (cm, fresh weight of bulb (g) and bulb yield ( $\mathrm{t} \mathrm{ha}^{-1}$ ) of Garlic (Allium sativum $\mathrm{L}$.) at different intervals

\begin{tabular}{|c|c|c|c|c|c|}
\hline $\begin{array}{c}\text { Treatment } \\
\text { No. }\end{array}$ & Treatments & \begin{tabular}{|c|} 
Polar \\
diameter of bulb $(\mathrm{cm})$ \\
\end{tabular} & $\begin{array}{c}\text { Equatorial diameter of bulb } \\
(\mathrm{cm})\end{array}$ & $\begin{array}{l}\text { Bulb fresh } \\
\text { weight }(g)\end{array}$ & $\begin{array}{c}\text { Bulb yield } \\
\left(\mathrm{q} \mathrm{ha} \mathbf{h}^{-1}\right)\end{array}$ \\
\hline $\mathrm{T}_{0}$ & Control & 4.18 & 3.95 & 34.90 & 71.11 \\
\hline $\mathrm{T}_{1}$ & FYM $25 \mathrm{t} \mathrm{ha}^{-1}$ & 4.92 & 4.09 & 49.83 & 101.92 \\
\hline $\mathrm{T}_{2}$ & FYM $25 \mathrm{t} \mathrm{ha}^{-1}+$ NPK 100:75:75 $\mathrm{kg} \mathrm{ha}^{-1}$ & 5.73 & 4.19 & 66.83 & 149.63 \\
\hline $\mathrm{T}_{3}$ & FYM $25 \mathrm{t} \mathrm{ha}^{-1}+$ NPK 120:75:75 $\mathrm{kg} \mathrm{ha}^{-1}$ & 5.82 & 4.67 & 70.60 & 136.29 \\
\hline $\mathrm{T}_{4}$ & FYM $20 \mathrm{t} \mathrm{ha}^{-1}$ & 5.54 & 4.09 & 62.83 & 106.66 \\
\hline $\mathrm{T}_{5}$ & FYM 20 t ha $^{-1}+$ NPK 100:75:75 $\mathrm{kg} \mathrm{ha}^{-1}$ & 6.22 & 5.16 & 84.60 & 195.55 \\
\hline $\mathrm{T}_{6}$ & FYM 20 t ha $^{-1}+$ NPK 120:75:75 $\mathrm{kg} \mathrm{ha}^{-1}$ & 5.83 & 4.73 & 76.17 & 157.44 \\
\hline $\mathrm{T}_{7}$ & NPK 100:75:75 kg ha-1 & 5.44 & 4.23 & 60.25 & 114.62 \\
\hline $\mathrm{T}_{8}$ & NPK 120:75:75 kg ha ${ }^{-1}$ & 5.27 & 4.16 & 55.33 & 88.74 \\
\hline & $\begin{array}{c}\text { F-test } \\
\text { S.Ed. }( \pm) \text { C. D. }(\mathrm{P}=0.05)\end{array}$ & $\begin{array}{c}\mathrm{S} \\
0.389,0.802\end{array}$ & $\begin{array}{c}\mathrm{S} \\
0.333,0.687\end{array}$ & \begin{tabular}{|c|}
$\mathrm{S}$ \\
$10.362,21.386$
\end{tabular} & $\begin{array}{c}\mathrm{S} \\
29.587,61.068\end{array}$ \\
\hline
\end{tabular}

\section{Conclusion}

Based on the results of the present study, the planting of Garlic Cv. Punjab Garlic in 2017 Winter season with application of $20 \mathrm{t}$ FYM +100:75:75 Kg/ha-1 may be safely recommended for the farmers of this area.

\section{References}

1. Ahmed Abbas, Sultan Muhammad, Muhammad Bashir, Akhtar Nawaz, Hakim Khan. Effect of various Levels of nitrogen, phosphorus and potash on the yield of garlic. Sarhad Journal of Agriculture, Pakistan 2006;22(1):83.
2. Banafer RNS, Namdeo SL, Asati KP. Effect of organic manures in combination with chemical fertilizers on growth, yield and quality of garlic. National seninar on opportunities and potentials of spices for crop diversification 2004, 188.

3. Devendra Singh, Nainwal RC, Katiyar RS, Tewari SK. CSIR-National Botanical Research Institute, Lucknow(UP) 226001 India 2014, 783-788.

4. Diriba-Shiferaw, Nigussie Dechassa, Kebede Woldetsadik, Getachew Tabor, Sharma JJ. Growth and nutrients content and uptake of garlic (Allium sativum L.) 
as influenced by different types of fertilizers and soils. African journal of agricultural research 2013;8(43):98.

5. Getachew Tabour, Asfaw Zelleke. Achievements in shallot and garlic research. Report No. 36.Ethiopian Agricultural Research Organization, Addis Ababa Ethiopia 2000, 56.

6. Gowda MC, Vijayakumar M, Gowda APM. Influence of integrated nutrient management on growth, yield and quality of garlic (Allium sativum L.) cv. G-282. Crop Res. Hisar 2007;33(1-3):144-147.

7. Islah ME. Response of garlic (Allium sativum L.) to some sources of organic fertilizers under North Sinai conditions. Research Journal of Agriculture and Biological Sciences 2010;6(6):928-936.

8. Kakar AA, Abdullahzai MK, Saleem M, Qaim SA. Effect of Nitrogenous fertilizer on Growth and yield of Garlic. Asian Journal of plant sciences Pakistan 2002;1(5):544545.

9. Kilgori MJ, Magaji MD, Yakubu AI. Productivity of two garlic (Allium sativum L.) cultivars as affected by different levels of nitrogenous and phosphorus fertilizers in Sokota, Nigeria. American-Eurasian J. Agric. and Environ. Sci 2007;2(2):158-162.

10. Moravcevic D, Varga JG, Pavlovic N, Todorovic V, Ugrinovic M. Production and chemical characteristics of the populations of spring garlic (Allium Sativum L.) from the serbian genetic collection. Emirates Journal of Food and Agriculture 2017, 227-236.

11. Singh S, Yadav PK, Singh B. Effect of nigrogen and potassium on growth and yield of onion (Allium cepa L.) cv. Pusa red. Hariyana, J. Hort. Sci 2004;33(3,4):308309.

12. Tadila G, Nigusie D. Effect of manure and nitrogen rates on growth and yield of garlic (Allium sativum L.) at Haramaya, Eastern Ethiopia 2018. 